\title{
Effect of Eugenia jambolana and Psidium guajava Leaf Meal Mixture Supplementation on Performance, Biochemical Profile and Histopathological Changes of Broiler Chicks
}

\author{
M.A. Zargar, A.K. Pathak*, S. Rahman, R.K. Sharma and M.I. Daing \\ Division of Animal Nutrition, Faculty of Veterinary Sciences $\mathcal{E}$ AH, Sher-e-Kashmir University of Agricultural Sciences and \\ Technology of Jammu, R. S. Pura, (J \& K), INDIA \\ "Corresponding author: AK Pathak; E-mail: dranand_pathak@yahoo.com
}

Received: 02 Nov., 2019

Revised: 12 Jan., 2020

Accepted: 21 Jan., 2020

\begin{abstract}
Present study was undertaken in 120 day-old broiler chicks, randomly distributed into 4 dietary treatments $\left(\mathrm{T}_{1}, \mathrm{~T}_{2}, \mathrm{~T}_{3}\right.$ and $\mathrm{T}_{4}$ supplemented with leaf meal mixture (LMM) of Eugenia jambolana and Psidium guajava @ 0, 2.5, 5.0 and 7.5\% of diet, respectively) each having 3 replicates (10 chicks/ replicate) in a complete randomized block design (CRD). Experimental chicks were fed basal diets (starter and finisher) supplemented with graded levels of LMM. Feed intake, body weight gain and feed conversion ratio (FCR) were recorded at weekly intervals. Two birds from each replicate were slaughtered at the end of feeding trial (42 days). Blood samples were collected and serum separated for biochemical profiles. For histopathological examination, representative tissue samples were collected in $10 \%$ neutral buffer formalin and then processed for paraffin embedding employing alcohol as dehydrating agent and xylene as clearing agent. Sections were cut at $4-5 \mu \mathrm{m}$ thickness and stained by routine haematoxylin and eosin method. On histopathological examination of liver, kidney, heart and intestine of $\mathrm{T}_{1}$ and $\mathrm{T}_{2}$ groups showed normal integrity, mild to moderate histopathological changes in $\mathrm{T}_{3}$ group, while, $\mathrm{T}_{4}$ showed drastic histopathological changes. It was concluded that E. jambolana and P. guajava LMM supplementation (2.5\% or even 5\%) maintained birds performance, minor histopathological changes and producing healthy low cholesterol broiler meat. The LMM incorporation $(2.5 \%)$ in the diet of broiler chicks may be recommended as socioeconomic, alternative functional feed resource.
\end{abstract}

Keywords: Biochemical profile; Broilers; Histopathology; Leaf meal mixture

Poultry provides an immense supply of animal protein for the world's human population. It is one of the most profitable businesses in agriculture as it provides nutritious meat and eggs within a short period of time $\left(19^{\text {th }}\right.$ Livestock Census, 2012). Poultry play a significant role in conversion of plant materials into high quality protein rich food. Broiler industry has become rapidly developing enterprise among other sectors of poultry production. The rapidly changing patterns of demand for broiler meat and meat products, point to broiler production being an increasing component of the agricultural economies of Asia. The extent to which the rural poor will benefit from these changes depends on how poultry farming can be integrated into developing markets and whether cheaper meat and meat products benefit the rural poor as consumers as well as producers (Jung et al., 2011).

Tree leaves, leaf meal (LM) and/or leaf meal mixture (LMM) produce wide ranges of active compounds (like Condensed tannins; CT) that provide many beneficial effects (Pathak, 2013; 2017) like natural feed additives, immune stimulator (Pathak et al., 2016; Singh et al., 2015), growth promoter, alternative feed supplements (Pathak et al., 2013a) and various pharmacological effects viz. antioxidants (Daing et al., 2017a,b; Pathak et al.,

How to cite this article: Zargar, M.A., Pathak, A.K., Rahman, S., Sharma R.K. and Daing, M.I. (2020). Effect of Eugenia jambolana and Psidium guajava leaf meal mixture supplementation on performance, biochemical profile and histopathological changes of broiler chicks. J. Anim. Res. 10(2): 221-230. 
2017; Zargar et al., 2016, 2017) anthelmintic (Pathak et al., 2013a,b,c; Singh et al., 2015), antibacterial (Daing et al., 2017a,b) and anticoccidial (Zargar et al., 2016, 2017). Generally, the active compounds do not play an important role in the metabolism of trees, so it is often referred to as plant secondary metabolites (PSM). The PSM have long been known as a source of effective medical therapies and works as important natural feed additives in poultry production.

Moreover, LMM is one of the possible sources of cheap feedstuff that have been incorporated in the diets of poultry as a means of reducing the high cost of conventional feed sources. It was reported that LM or LMM not only serve as protein source but also provide some necessary vitamins, minerals and active compounds like growth promoters and produce low cholesterol healthy meat (Kakengi et al., 2007). Therefore, this raises the possibility that the incorporation of potential source and suitable dose level of CT containing LMM may be an alternative sustainable approach to reduces the cost of production and improve the performance of broiler chicken. Keeping this in view, it is proposed to explore the effect of E. jambolana and $P$. guajava LMM on performance, biochemical profiles and organ histopathology of broiler chickens.

\section{MATERIALS AND METHODS}

\section{Experimental Site}

The experimental study was undertaken in the Division of Animal Nutrition, Faculty of Veterinary Sciences \& AH, Sher-e-Kashmir University of Agricultural Sciences and Technology of Jammu, R. S. Pura-181102. Fresh leaves of E. jambolana and P. guajava were harvested from Faculty premises. Both tree leaves were air-dried in the shed for 12-15 days. The dried leaves were micronized with a hammer mill into fine powder, weighed and kept in sterile containers for use later. The fine powder of both tree leaves were thoroughly mixed in proper ratio (50:50) on the cemented floor and suitable LMM was prepared for in-vivo trial.

\section{Experimental Feeds and Nutritional analysis}

The basal (starter and finisher) diets were formulated according to BIS (1992) using locally available feed ingredients to fulfil the nutrient requirements of broiler chicks. The LMM was incorporated into the diets at the rate of $0.0 \%\left(\mathrm{~T}_{1}\right), 2.5 \%\left(\mathrm{~T}_{2}\right), 5.0 \%\left(\mathrm{~T}_{3}\right)$ and $7.5 \%\left(\mathrm{~T}_{4}\right)$. The $T_{1}$ is control while others $\left(T_{2}, T_{3}\right.$ and $\left.T_{4}\right)$ are LMM supplemented groups. The ingredient composition of experimental broiler diets is shown in the table 1 . The LMM and experimental diets were subjected chemical analysis in triplicates according to the method of AOAC (1995). Nitrogen free extract (NFE) was determined by difference between 100 and the sum of crude protein $(\mathrm{CP})$, ether extract (EE), crude fibre (CF) and total ash (TA) values on dry matter (DM) basis. Calcium (Ca) was determined as per Talpatra et al. (1940) and phosphorus (P) content by spectrophotometric method (AOAC, 2000). Condensed tannins (CT) content of LMM was determined by butanol-Hcl method (Makkar, 2000). All chicks were provided fresh clean drinking water and feed ad-libitum throughout the experimental period in the morning and evening.

\section{Experimental birds, design, feeding and management}

A total of 120 unsexed day old healthy commercial broiler chicks (Cobb-K strains) were procured from Jammu. Chicks were reared in electric brooder until 7 days of age. Chicks had free access to feed and water throughout and were maintained on a constant 24 hours light schedule. On eighth day, chicks were individually weighed, distributed into 4 treatment groups of 3 replicates with 10 chicks in deep litter pen in a completely randomized block design (CRD). Chicks in control group were fed basal diets without LMM $\left(\mathrm{T}_{1}\right)$, while other 3 treatment groups were fed the basal diet supplemented with E. jambolana and $P$. guajava LMM at the rate of 2.5, 5.0 and 7.0 percent in $\mathrm{T}_{2}$, $\mathrm{T}_{3}$ and $\mathrm{T}_{4}$ groups, respectively.

Experimental house and brooding pens were thoroughly cleaned, disinfected, fumigated and remain closed for a period of 15 days before the arrival of chicks. All the feeders, drinkers and other utensils were thoroughly washed and disinfected. The brooding and deep litter materials were properly dried. Rice husks used as litter materials were spread on the floor of the pen and a warm temperature of $33-35{ }^{\circ} \mathrm{C}$ was maintained in the brooder with electric bulbs before the arrival of chicks and thereafter 7 days of age. On arrival, the chicks were carefully unboxed, weighed and brooded for a period of 
7 days before they were randomly allocated to 4 dietary treatments. The temperature of poultry house gradually declined to $27^{\circ} \mathrm{C}$ by 21 days of age, after which, chicks were maintained at room temperature $\left(25-27^{\circ} \mathrm{C}\right)$. All the chicks were provided same care and good management practices.

\section{Sample collection and biochemical constituents}

Data on the feed intake, body weight gains and FCR were determined on weekly basis. The FCR was computed as feed intake divided by body weight gain. Blood samples were collected on 42 days at the time of slaughter. Two birds were randomly selected from each replicate for bleeding and slaughter. About $4 \mathrm{ml}$ blood from each bird was collected in sterile centrifuge tube for serum collection and it was stored in sample vials at $-20^{\circ} \mathrm{C}$ for estimation of biochemical constituents i.e. glucose (Teitz, 1976), total serum protein (Tietz, 1986), albumin (Doumas et al., 1972), creatinine (Newman and Price, 1999), cholesterol (Roeschlau et al., 1974), triglyceride (Cole et al., 1997) and serum enzymes viz. serum glutamic oxaloacetic transaminase (SGOT; Bergmeyer et al., 1986a), serum glutamic pyruvic transaminase (SGPT; Bergmeyer et al., 1986b), alkaline phosphatase (ALP; Bessey et al., 1946) and lactate dehydrogenase (LDH; Henry et al., 1960). The biochemical profiles were determined by using readymade diagnostic (Erba Diagnostics Mannheim $\mathrm{GmbH}$ ) kits.

\section{Histopathological studies}

For histopathological examination, representative tissue samples of various visceral and immune organs were collected in $10 \%$ neutral buffer formalin and then processed for paraffin embedding employing alcohol as dehydrating agent and xylene as clearing agent. The sections were cut at $4-5 \mu \mathrm{m}$ thickness and stained by routine Harris haematoxylin and eosin method (Suvarna et al., 2012).

\section{Statistical analysis}

Results obtained were subjected to analysis of variance and treatment means were ranked using Duncan's multiple range test. Periodic alterations in feed intake, body weight gain and FCR were analyzed using General linear model multivariate procedure of SPSS (16.0) software considering replicates as experimental units and the values were expressed as means \pm standard error. Degree of freedom of the treatments was portioned into orthogonal polynomial, depicting linear and quadratic trends associated with increasing levels of CT containing LMM supplementation. Significance was declared at $\mathrm{P}<0.05$ unless otherwise stated. Statistical procedures were done as per Snedecor and Cochran (2004).

\section{RESULTS AND DISCUSSION}

\section{Nutrient and chemical composition of experimental diets}

The ingredients composition of experimental diets is presented in the table 1. Various feed ingredients viz. maize, rice polish, soybean meal, meat cum bone meal (MBM), soybean oil, di-calcium phosphate, lime stone powder, salt, mineral mixture and vitamin premix, L-lysine and DL-methionine were procured from local market for formulation of broiler starter and finisher diets as per BIS (1992). In the basal (starter and finisher) diets LMM of E. jambolana and P. guajava (50:50 ratio) was incorporated @ 0, 2.5, 5.0 and 7.5\% in $\mathrm{T}_{1}, \mathrm{~T}_{2}, \mathrm{~T}_{3}$ and $\mathrm{T}_{4}$ diets, respectively by replacing maize so as to maintain iso-nitrogenous diets throughout the experimental period. The proximate composition of broiler starter and finisher diets of all experimental chicks were within the range as suggested by BIS (1992).

The OM, CP, EE, CF, NFE, TA, AIA, Ca and P content on (\% DM) bases of broiler starter diets were 92.55, 22.93, $4.45,4.42,60.75,7.45,2.43,1.67 \& 0.76 ; 92.43,22.83$, $4.40,4.53,60.67,7.57,2.61,1.64 \& 0.77 ; 92.11,22.97$, $4.23,4.69,60.22,7.89,2.78,1.77 \& 0.73$ and 91.99 , 23.07, 4.64, 4.82, 59.46, 8.01, 2.92, $1.83 \& 0.70$ percent, whereas, the OM, CP, EE, CF, NFE, total ash, AIA, Ca and $\mathrm{P}$ content on $(\% \mathrm{DM})$ bases of broiler finisher diets were $92.14,20.01,5.04,4.63,62.46,7.86,2.50,1.73 \&$ $0.69 ; 92.08,20.13,5.12,4.38,62.45,7.92,2.43,1.56 \&$ $0.67 ; 91.97,19.81,5.22,4.72,62.20,8.03,2.76,1.83 \&$ 0.63 , and $91.88,19.80,5.07,4.83,62.18,8.12,2.91,1.77$ \& 0.61 percent, respectively in $\mathrm{T}_{1}, \mathrm{~T}_{2} \mathrm{~T}_{3}$ and $\mathrm{T}_{4}$ groups. The ME (Kcal/kg diet) contents were 2818, 2790, 2762, 2734 and 2925, 2897, 2869, 2841, for broiler starter and finisher diets, respectively in $\mathrm{T}_{1}, \mathrm{~T}_{2} \mathrm{~T}_{3}$ and $\mathrm{T}_{4}$ groups. The incorporation of LMM of E. jambolana and P. guajava 
Table 1: Ingredients composition of experimental broiler diets

\begin{tabular}{|c|c|c|c|c|c|c|c|c|}
\hline \multirow{3}{*}{ Ingredients } & \multicolumn{8}{|c|}{ Experimental diets } \\
\hline & \multicolumn{4}{|c|}{ Broiler starter } & \multicolumn{4}{|c|}{ Broiler finisher } \\
\hline & $\mathbf{T}_{1}$ & $\mathbf{T}_{2}$ & $\mathbf{T}_{3}$ & T4 & $\mathbf{T}_{1}$ & $\mathbf{T}_{2}$ & $\mathbf{T}_{3}$ & T4 \\
\hline Crushed maize & 51.00 & 48.50 & 46.00 & 43.50 & 57.00 & 54.50 & 52.00 & 49.50 \\
\hline Rice polish & 3.75 & 3.75 & 3.75 & 3.75 & 6.50 & 6.50 & 6.50 & 6.50 \\
\hline Soybean meal & 35.00 & 35.00 & 35.00 & 35.00 & 27.50 & 27.50 & 27.50 & 27.50 \\
\hline Meat cum bone meal & 5.00 & 5.00 & 5.00 & 5.00 & 4.00 & 4.00 & 4.00 & 4.00 \\
\hline Soybean oil & 1.75 & 1.75 & 1.75 & 1.75 & 2.00 & 2.00 & 2.00 & 2.00 \\
\hline Di-calcium phosphate & 1.16 & 1.16 & 1.16 & 1.16 & 1.00 & 1.00 & 1.00 & 1.00 \\
\hline Lime stone powder & 1.00 & 1.00 & 1.00 & 1.00 & 0.70 & 0.70 & 0.70 & 0.70 \\
\hline Iodised salt & 0.40 & 0.40 & 0.40 & 0.40 & 0.40 & 0.40 & 0.40 & 0.40 \\
\hline Premix (Min. and Vit.) & 0.47 & 0.47 & 0.47 & 0.47 & 0.45 & 0.45 & 0.45 & 0.45 \\
\hline Lysine-Hcl & 0.31 & 0.31 & 0.31 & 0.31 & 0.30 & 0.30 & 0.30 & 0.30 \\
\hline DL-Methionine & 0.16 & 0.16 & 0.16 & 0.16 & 0.15 & 0.15 & 0.15 & 0.15 \\
\hline Leaf meal mixture & 0.00 & 2.50 & 5.00 & 7.50 & 0.00 & 2.50 & 5.00 & 7.50 \\
\hline
\end{tabular}

(a) $0,2.5,5.0$ and $7.5 \%$ by replacing maize slightly altered the nutrient composition of experimental diets but its incorporation not caused so much difference in the nutritive values of experimental $\left(\mathrm{T}_{1}, \mathrm{~T}_{2}, \mathrm{~T}_{3}\right.$ and $\left.\mathrm{T}_{4}\right)$ diets.

\section{Performance parameters}

The data of weekly feed intake, body weight gain and feed conversion ratio of all experimental chicks are presented in the table 2. The average feed intake $(\mathrm{g})$ decreased significantly $(\mathrm{P}<0.05)$ as the level of LMM increased. Significantly $(\mathrm{P}<0.05)$ higher feed intake was recorded in $\mathrm{T}_{1}$ compared to $\mathrm{T}_{3}$ and $\mathrm{T}_{4}$, whereas, $\mathrm{T}_{2}$ had an intermediate value between $T_{1}$ and $T_{3}$.

The lower feed intake in $\mathrm{T}_{3}$ and $\mathrm{T}_{4}$ of LMM supplemented groups might be due to high $\mathrm{CT}$ content because $\mathrm{CT}$ having astringent property and at higher level it bind with glycol-proteins with some of the salivary protein and other nutrients, such complex causes a sensation in the oral cavity, which greatly reduced palatability and hence tends to depress the feed intake in broiler birds. Similar results have been reported elsewhere (Dube, 1993). Present results are contradictory to the findings of Rahman et al. (2013). They had observed that $P$. guajava leaf meal up to $4.5 \%$ dietary level had no detrimental effect on feed consumption.

Significantly $(\mathrm{P}<0.05)$ higher mean body weight gain $(\mathrm{g})$ were observed in $\mathrm{T}_{1}$ as compared to $\mathrm{T}_{2}, \mathrm{~T}_{3}$ and $\mathrm{T}_{4}$ groups, while body weight gains between $\mathrm{T}_{2}, \mathrm{~T}_{3}$ and $\mathrm{T}_{4}$ groups were showed non-significant difference. As the time period of experimental study increased, mean body weight gain of broiler chicks increased significantly $(\mathrm{P}<0.05)$. The maximum mean body weight gain of broiler birds was recorded at $5^{\text {th }}$ week followed by $4^{\text {th }}, 6^{\text {th }}, 3^{\text {rd }}, 2^{\text {nd }}$ and least body weight gain was obtained at $1^{\text {st }}$ week. The mean FCR among all four groups ranged from 2.08 to 2.28.

Significantly $(\mathrm{P}<0.05)$ better FCR was obtained in unsupplemented $\left(\mathrm{T}_{1}\right)$ group than that of LMM supplemented $\left(\mathrm{T}_{2}, \mathrm{~T}_{3}\right.$ and $\left.\mathrm{T}_{4}\right)$ groups. The FCR when compared among weekly intervals significantly $(\mathrm{P}<0.05)$ better FCR was obtained in $2^{\text {nd }}$ week (1.40) followed by $1^{\text {st }}$ week (1.91), $3^{\text {rd }}$ week (2.06), $4^{\text {th }}$ week $(2.50)$ and the worst FCR in $6^{\text {th }}$ week (2.85). Similarly, El-Deek et al. (2009) study found that feeding of guava by-products, raw or treated with the higher levels (6-8 \%) showed slightly reduction of broiler body weight gain. Present findings are confirmatory with the results of Shafey et al. (2013) who reported that the replacement of higher levels of Olive leaves reduced body weight gain and feed conversion efficiency in broiler chicks. But contradictory with the results of Simol et al. (2012), whose study showed that mulberry leaf powder can substitute up to $30 \%$ of commercial feed without any adverse effect on the feed intake, growth performance and FCR of broiler chicken.

\section{Biochemical profile}

The biochemical profile of broiler birds supplemented graded level of LMM is presented in table 3. Blood 
Table 2: Effect of E. jambolana and P. guajava LMM supplementation on feed intake, body weight gain and FCR of broiler chicks

\begin{tabular}{|c|c|c|c|c|c|}
\hline \multirow{2}{*}{ Periods (in Weeks) } & \multicolumn{4}{|c|}{ Groups } & \multirow{2}{*}{ Mean \pm SE } \\
\hline & $\mathbf{T}_{1}$ & $\mathbf{T}_{2}$ & $T_{3}$ & $\mathbf{T}_{4}$ & \\
\hline \multicolumn{6}{|c|}{ Feed intake (g) } \\
\hline 1st & 148.33 & 141.67 & 140.00 & 150.00 & $145.00^{\mathrm{a}} \pm 0.39$ \\
\hline $2^{\text {nd }}$ & 285.00 & 278.33 & 283.33 & 281.67 & $282.08^{b} \pm 0.23$ \\
\hline $3^{\text {rd }}$ & 652.00 & 632.00 & 611.33 & 565.00 & $615.08^{c} \pm 2.96$ \\
\hline $4^{\text {th }}$ & 935.00 & 910.00 & 903.67 & 835.33 & $896.00^{\mathrm{d}} \pm 3.39$ \\
\hline $5^{\text {th }}$ & 1004.67 & 980.67 & 965.00 & 935.33 & $971.42^{\mathrm{e}} \pm 2.31$ \\
\hline $6^{\text {th }}$ & 995.67 & 975.00 & 962.67 & 913.67 & $961.75^{\mathrm{e}} \pm 2.76$ \\
\hline Mean $\pm \mathbf{S E}$ & $670.11^{c} \pm 25.69$ & $652.95^{\mathrm{bc}} \pm 25.15$ & $644.33^{b} \pm 24.74$ & $613.50^{\mathrm{a}} \pm 23.04$ & \\
\hline \multicolumn{6}{|c|}{ Body weight gain $(g)$} \\
\hline $1 \mathrm{st}$ & 87.33 & 77.57 & 82.00 & 77.39 & $81.07^{\mathrm{a}} \pm 1.60$ \\
\hline $2^{\text {nd }}$ & 213.28 & 201.50 & 210.92 & 309.31 & $233.75^{\mathrm{b}} \pm 22.79$ \\
\hline $3^{\text {rd }}$ & 326.33 & 314.33 & 299.00 & 202.00 & $285.42^{\mathrm{c}} \pm 24.40$ \\
\hline $4^{\text {th }}$ & 438.27 & 368.83 & 353.83 & 370.67 & $382.90^{\mathrm{e}} \pm 8.24$ \\
\hline $5^{\text {th }}$ & 459.37 & 402.60 & 377.73 & 404.97 & $411.17^{\mathrm{f}} \pm 10.90$ \\
\hline $6^{\text {th }}$ & 349.23 & 360.20 & 343.40 & 329.90 & $345.68^{\mathrm{d}} \pm 4.99$ \\
\hline Mean \pm SE & $312.30^{\mathrm{b}} \pm 10.43$ & $287.51^{\mathrm{a}} \pm 9.67$ & $277.81^{\mathrm{a}} \pm 8.71$ & $282.37^{\mathrm{a}} \pm 24.08$ & \\
\hline \multicolumn{6}{|c|}{$\begin{array}{l}\text { Feed conversion ratio }(\mathrm{FCR}) \\
\end{array}$} \\
\hline 1 st & 1.73 & 1.91 & 1.81 & 2.17 & $1.91^{\mathrm{b}} \pm 0.06$ \\
\hline $2^{\text {nd }}$ & 1.37 & 1.47 & 1.42 & 1.33 & $1.40^{\mathrm{a}} \pm 0.03$ \\
\hline $3^{\text {rd }}$ & 2.07 & 2.08 & 2.07 & 2.02 & $2.06^{\mathrm{c}} \pm 0.05$ \\
\hline $4^{\text {th }}$ & 2.18 & 2.55 & 2.60 & 2.68 & $2.50^{\mathrm{d}} \pm 0.09$ \\
\hline $5^{\text {th }}$ & 2.25 & 2.55 & 2.69 & 2.59 & $2.52^{\mathrm{de}} \pm 0.05$ \\
\hline $6^{\text {th }}$ & 2.88 & 2.74 & 2.90 & 2.88 & $2.85^{\mathrm{e}} \pm 0.04$ \\
\hline Mean $\pm \mathbf{S E}$ & $2.08^{\mathrm{a}} \pm 0.04$ & $2.22^{\mathrm{b}} \pm 0.04$ & $2.25^{b} \pm 0.05$ & $2.28^{b} \pm 0.09$ & \\
\hline
\end{tabular}

${ }_{\text {abcdef }}$ Means with different superscript within a row and column differ significantly $(\mathrm{P}<0.05)$.

Table 3: Effect on biochemical profile of broiler finisher chicks fed E. jambolana and P. guajava LMM supplemented diets

\begin{tabular}{|c|c|c|c|c|c|c|}
\hline \multirow{2}{*}{ Parameters } & \multicolumn{4}{|c|}{ Group } & \multirow{2}{*}{ SEM } & \multirow{2}{*}{ P Value } \\
\hline & T1 & $\mathbf{T 2}$ & T3 & T4 & & \\
\hline Glucose (mg/dl) & 190.65 & 207.38 & 192.03 & 204.20 & 3.06 & 0.119 \\
\hline Total Protein (g/dl) & $5.06^{\mathrm{b}}$ & $5.09^{\mathrm{b}}$ & $4.40^{\mathrm{a}}$ & $4.14^{\mathrm{a}}$ & 0.11 & 0.000 \\
\hline Albumin (g/dl) & $3.10^{\mathrm{b}}$ & $2.13^{\mathrm{a}}$ & $2.12^{\mathrm{a}}$ & $2.05^{\mathrm{a}}$ & 0.10 & 0.000 \\
\hline Globulin (g/dl) & $1.96^{\mathrm{a}}$ & $2.96^{\mathrm{b}}$ & $2.28^{\mathrm{a}}$ & $2.10^{\mathrm{a}}$ & 0.10 & 0.000 \\
\hline A:G Ratio & $1.60^{\mathrm{b}}$ & $0.73^{\mathrm{a}}$ & $0.96^{\mathrm{a}}$ & $0.98^{\mathrm{a}}$ & 0.08 & 0.000 \\
\hline Cholesterol (mg/dl) & $147.68^{\mathrm{c}}$ & $132.47^{\mathrm{b}}$ & $116.45^{\mathrm{a}}$ & $111.38^{\mathrm{a}}$ & 3.22 & 0.000 \\
\hline Triglyceride (mg/dl) & $53.81^{\mathrm{c}}$ & $46.04^{\mathrm{b}}$ & $42.78^{\mathrm{b}}$ & $31.24^{\mathrm{a}}$ & 1.87 & 0.000 \\
\hline Creatinine (mg/dl) & $1.30^{\mathrm{a}}$ & $1.42^{\mathrm{a}}$ & $1.46^{\mathrm{a}}$ & $1.82^{\mathrm{b}}$ & 0.06 & 0.005 \\
\hline SGPT (IU/L) & $12.38^{\mathrm{a}}$ & $11.94^{\mathrm{a}}$ & $13.26^{\mathrm{a}}$ & $17.98^{b}$ & 0.65 & 0.000 \\
\hline SGOT (IU/L) & $109.91^{\mathrm{a}}$ & $108.44^{\mathrm{a}}$ & $108.73^{\mathrm{a}}$ & $119.34^{\mathrm{b}}$ & 1.76 & 0.076 \\
\hline ALP (IU/L) & $301.60^{\mathrm{b}}$ & $273.34^{\mathrm{ab}}$ & $287.97^{\mathrm{ab}}$ & $258.39^{\mathrm{a}}$ & 6.36 & 0.081 \\
\hline LDH (IU/L) & $62.06^{\mathrm{a}}$ & $63.41^{\mathrm{a}}$ & $64.76^{\mathrm{a}}$ & $78.25^{\mathrm{b}}$ & 2.41 & 0.051 \\
\hline
\end{tabular}

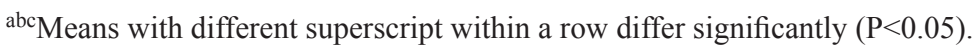


glucose level is an indicator of the normal physiology and well being of poultry. An increased or decreased level of blood glucose level is an indicator of stress to the birds. There were no significant differences $(\mathrm{P}>0.05)$ in blood glucose level among all groups with and without LMM supplementation and the glucose values were within the normal range (Kenako, 1997). However, in present study, analogous glucose level indicates normal physiological condition of all experimental birds. Total protein value was found to be lowest $(\mathrm{P}<0.000)$ in $\mathrm{T}_{3} \& \mathrm{~T}_{4}$ than that of $T_{1} \& T_{2}$ but the values were statistically similar between $\mathrm{T}_{1} \& \mathrm{~T}_{2}$ and $\mathrm{T}_{3} \& \mathrm{~T}_{4}$. It clearly indicated that dietary incorporation LMM $2.5 \%$ onward in broiler chicks had adversely affected the serum protein levels. However, total serum proteins were within the normal physiological range established for broiler chicks (Kenako, 1997).

Significantly $(\mathrm{P}<0.000)$ higher albumin level was recorded in $T_{1}$ as compared to $T_{2}, T_{3}$ and $T_{4}$. Significantly higher serum globulin level was obtained in LMM supplemented $\mathrm{T}_{2}$ groups compared to rest of the supplemented and unsupplemented groups. The globulin levels numerically increased in $\mathrm{T}_{3}$ and $\mathrm{T}_{4}$ groups than that of $\mathrm{T}_{1}$ group. Thus the elevated level of serum globulin in LMM supplemented groups clearly indicated that LMM supplementation was having immune stimulating property. The broiler chicks of $T_{1}$ group showed significantly $(P<0.000)$ higher $A: G$ ratio compared to rest of the supplemented groups but it was statistically similar among supplemented groups $\left(T_{2}\right.$, $\mathrm{T}_{3}$ and $\mathrm{T}_{4}$ ).

Serum cholesterol and triglyceride values were significantly lower in LMM supplemented groups than that of un-supplemented group. The low cholesterol and triglyceride content observed in the birds fed with CT containing LMM would have been as a result of the hypo-cholesterolemic and hypo-lipidemic properties of CT. Upadhyay (1990) also reported a decline in blood cholesterol levels of broilers and rats fed Neem leaf meal. Present results are in accordance with previous findings (Mahmoud et al., 2013) which affirmed that dietary supplementation of dried guava leaves reduced blood cholesterol and triglyceride levels in broilers.

Creatinine content is an indicator of kidney health status. Serum creatinine levels were significantly $(\mathrm{P}<0.005)$ higher in $\mathrm{T}_{4}$ as compared to $\mathrm{T}_{1}, \mathrm{~T}_{2}$ and $\mathrm{T}_{3}$ groups while statistically similar in $\mathrm{T}_{1}, \mathrm{~T}_{2}$ and $\mathrm{T}_{3}$. The higher creatinine level in $\mathrm{T}_{4}$ might be due to higher $\mathrm{CT}$ level $(7.5 \%)$ which may cause kidney damage.

There was significant difference $(\mathrm{P}<0.001)$ between the SGPT (IU/L) levels for $T_{4}$ and those of $T_{1}, T_{2}$ and $T_{3}$. There were no significant differences $(\mathrm{P}>0.05)$ in SGPT levels among the $\mathrm{T}_{1}, \mathrm{~T}_{2}$ and $\mathrm{T}_{3}$. Comparatively higher $(\mathrm{P}<0.076$, $\mathrm{P}<0.051)$ SGOT and LDH activities were obtained in $\mathrm{T}_{4}$ than that of $T_{1}, T_{2}$ and $T_{3}$ but there were no significant difference among SGOT and LDH levels for $\mathrm{T}_{1}, \mathrm{~T}_{2}$ and $\mathrm{T}_{3}$. The ALP (IU/L) activity in $T_{1}$ group was comparatively higher than that of in $\mathrm{T}_{4}$ group, whereas, $\mathrm{T}_{2}$ and $\mathrm{T}_{3}$ had an intermediate position between $T_{1}$ and $T_{4}$ which clearly indicated the higher weight gain in $\mathrm{T}_{1}$ group. Low cholesterol in broilers was also reported by Obikaonu et al. (2012). They studied the effects of dietary inclusion of neem leaf meal at $0,2.5,5.0,7.5$ and $10 \%$ levels on serum biochemical indices of broiler starter and found that blood sugar was raised by the leaf meal but cholesterol, ALP, ALT and AST levels decreased with increase in leaf meal.

\section{Histopathological examination}

On histopathological examination, liver of $T_{1}$ and $T_{2}$ groups showed normal hepatocytes arranged in cord pattern with central vein and portal triad (Fig. 1). Liver of $\mathrm{T}_{3}$ group showed mild to moderate hepatocytic degeneration (Fig. 2), however, $\mathrm{T}_{4}$ showed mono nuclear cells (MNC's) infiltration, fibrosis and peripheral hepatocytic degeneration (Fig. 3). Kidney of $T_{1}$ and $T_{2}$ did not show any significant microscopic changes. Nuclei of lining epithelial cells were vesicular and cytoplasm was homogenous, whereas, moderate swelling and degeneration of epithelial cells of tubules occluding the lumen was observes in $\mathrm{T}_{3}$ group (Fig. 4).

Moreover, kidney of $\mathrm{T}_{4}$ group showed interstitial haemorrhage, degeneration with vacuolar cytoplasm and necrosis of epithelial cells of tubules (Fig. 5). Heart of $T_{1}$ and $\mathrm{T}_{2}$ groups showed muscle fibres of uniform thickness and minimum of intermyofibral spaces. However, in $T_{3}$ group observed thinning of myocardial fibres (Fig. 6)), while, moderate necrosis of myocardial fibre was recorded in $T_{4}$ group (Fig. 7). Intestine of $T_{1}$ and $T_{2}$ groups showed normal intestinal villi, although, in $\mathrm{T}_{3}$ group observed mild degeneration of epithelial cells of intestinal villi (Fig. 8). However, fusion, blunting, desquamation of enterocytes and atrophy of villi with mild necrosis of enterocytes was observed in $\mathrm{T}_{4}$ group (Fig. 9). 


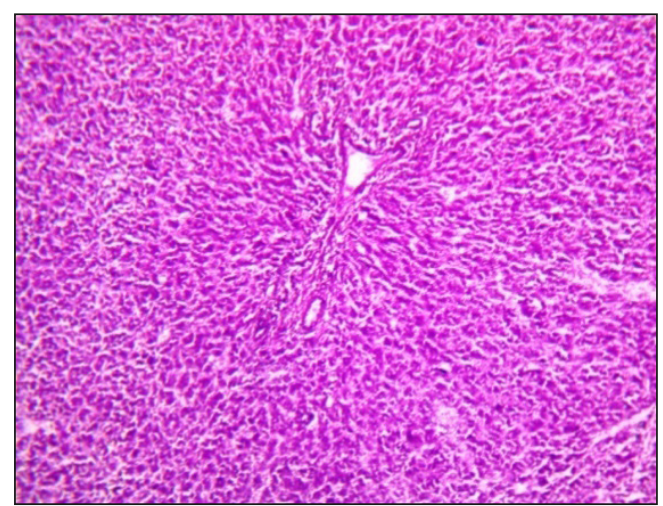

Fig. 1: Photomicrograph of liver depicting normal hepatocytes arranged in cord pattern. H\&E X 100

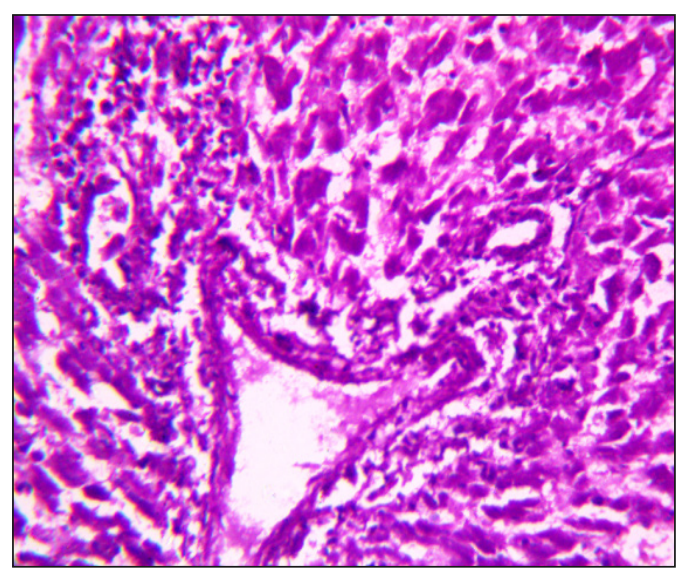

Fig. 3: Photomicrograph of liver depicting MNC's infiltration, Fig fibrosis and periportal hepatocytic degeneration H\&E X 400

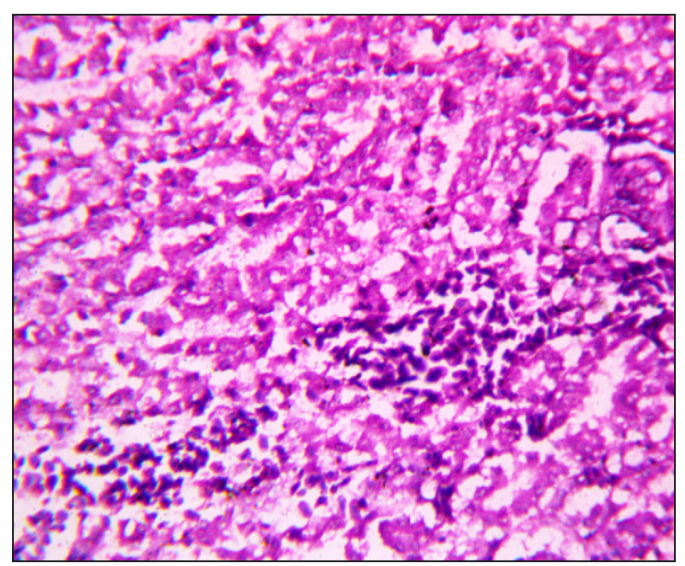

Fig. 5: Photomicrograph of kidney depicting interstitial haemorrhages, degeneration and necrosis of epithelial cells of tubules with vacuolar cytoplasm H\&E X 400

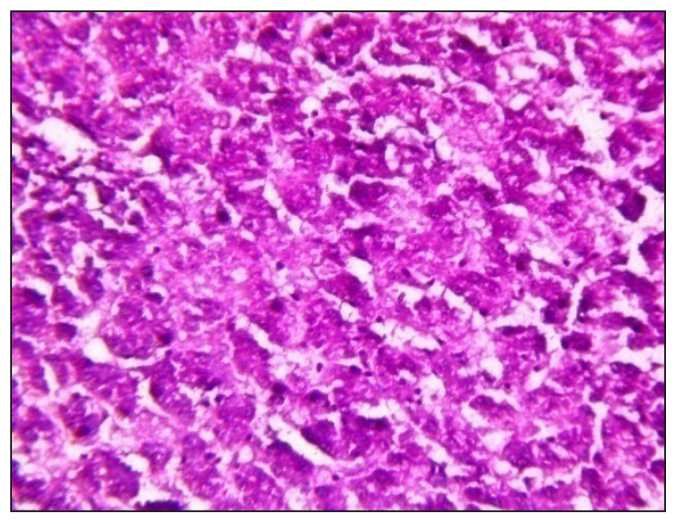

Fig. 2: Photomicrograph of liver depicting mild hepatocytic degeneration. H\&E X 400

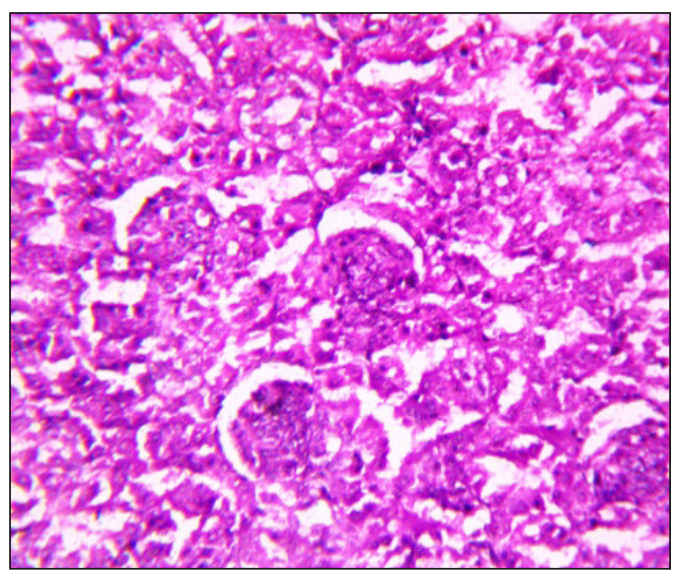
degeneration of epithelial cells of tubules occluding the lumen. $\mathrm{H} \& \mathrm{E}$ X 400

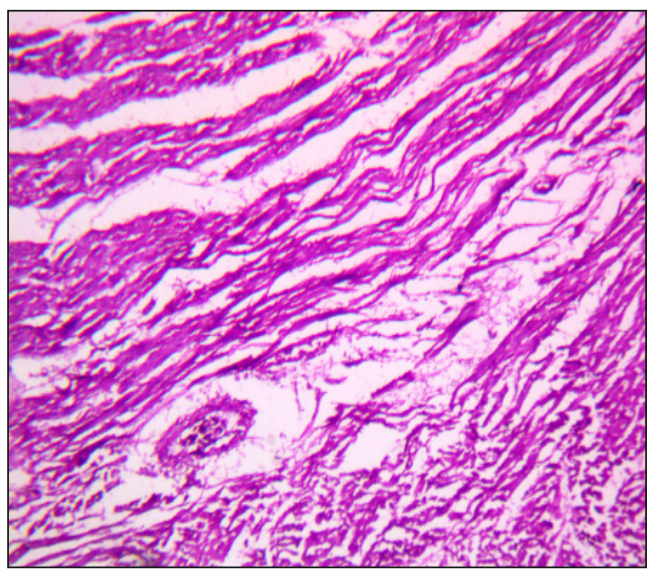

Fig. 6: Photomicrograph of heart depicting thinning and necrosis of myocardial fibres H\&E X 100 


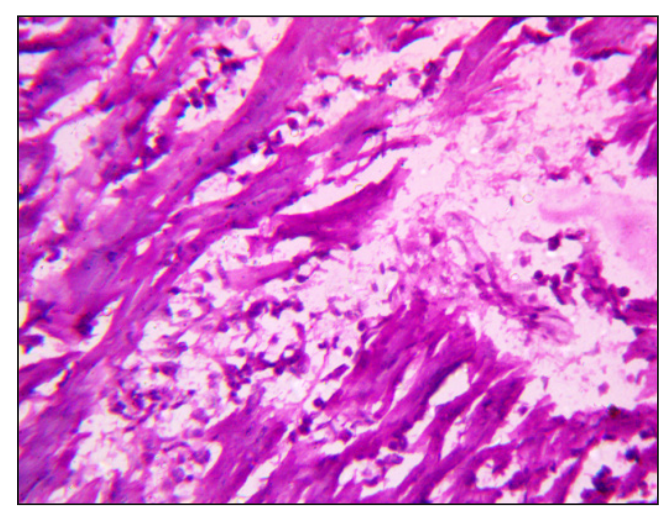

Fig. 7: Photomicrograph of heart depicting severe necrosis of myocardial fibres H\&E X 400

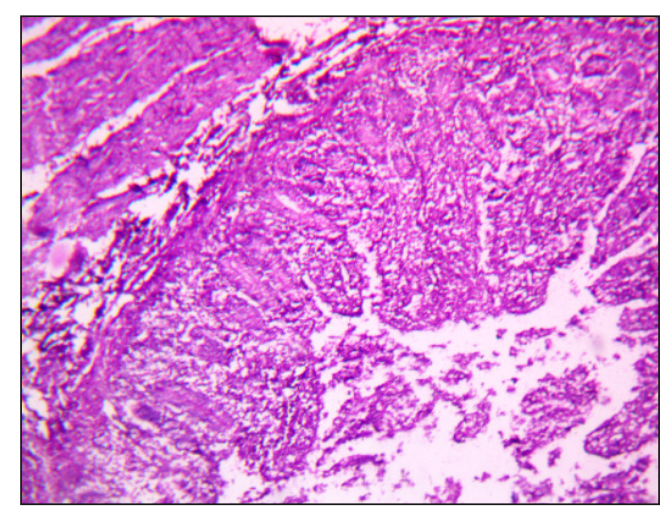

Fig. 8: Photomicrograph of intestine depicting fusion, blunting and desquamation of enterocytes of villi H\&E X 100

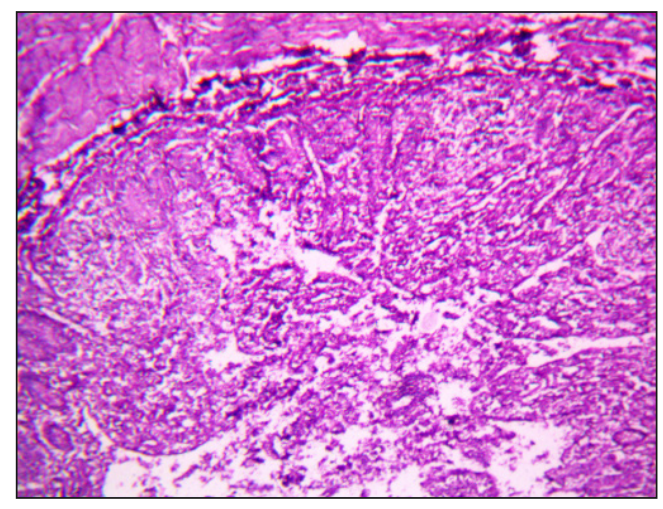

Fig. 9: Photomicrograph of intestine depicting fusion, blunting and atrophy of villi. Note the severe desquamation and necrosis of enterocytes of intestinal villi H\&E X 100

The observed changes and lesions in the photomicrographs of the examined vital organs (like liver, kidney heart and intestine) of the experimental chicks of higher level of LMM supplementation might be due to the higher CT level which act as anti-nutritional factors in LMM supplemented diets $(5-7.5 \%)$. The higher CT level in the diet of chicks cause toxicity and could affect architectural histology of liver, kidney, heart and intestine of experimental chicks. Present findings are confirmatory with the results of previous workers (Adejumo and Ologhobo, 2015; Ewuola, 2009 and Isaac et al., 2017) who also reported lesions on the visceral organs fed toxic substance in the diet of laying hens, rabbits and albino rats, respectively.

\section{CONCLUSION}

It can be concluded that condensed tannins containing leaf meal mixture of Eugenia jambolana and Psidium guajava $(2.5 \%)$ safely recommended as cost effective alternative feed resource perhaps it can be incorporated up to $5 \%$ level in broiler diets without any drastic changes.

\section{ACKNOWLEDGEMENTS}

Authors of the manuscript are thankful to Hon'ble Vice Chancellor, SKUAST-Jammu and worthy Dean, FVSc \& AH, R.S. Pura, Jammu for providing necessary facilities to carry out the research work.

\section{REFERENCES}

$19^{\text {th }}$ Livestock census, 2012. Published by Department of Animal Husbandry, dairying and Fisheries, Government of India.

Adejumo, I.O. and Ologhobo, A.D. 2015. Effect of insecticidetreated maize on heart and liver histology of laying chickens. J. Bio. Nat., 3(1): 21-25.

AOAC, 1995. Official methods of analysis ( $16^{\text {th }}$ ed.). Association of Official Analytical Chemists. Washington, DC. 
Bergmeyer, H.U., Horder, M. and Rej, R. 1986a. International Federation of Clinical Chemistry (IFCC) Scientific Committee, Analytical Section: Approved recommendation (1985) on IFCC methods for the measurement of catalytic concentration of enzymes. Part-2. IFCC method for aspartate aminotransferase (L-aspartate: 2- oxoglutarate aminotransferase, EC 2.6 1:1.). J. Clin. Chem. Clin. Biochem., 24: 497-510.

Bergmeyer, H.U., Horder, M., Rej, R. 1986b. International Federation of Clinical Chemistry (IFCC) Scientific Committee, Analytical Section: Approved recommendation (1985) on IFCC methods for the measurement of catalytic concentration of enzymes. Part-3. IFCC method for alanine aminotransferase (L-alanine: 2-oxoglutarate aminotransferase, EC 2.6 1:2.). J. Clin. Chem. Clin. Biochem., 24: 481-495.

Bessey, O.A., Lowry, O.H. and Brock, M.J. 1946. A method for the rapid determination of Alkaline phosphatise with five cubic millimetres of serum. J. Biol. Chem., 164: 321-329.

BIS, 1992. Indian standard poultry feed specifications, $4^{\text {th }}$ Rev. IS 1374: pp. 1-3.

Cole, T.G., Klotzsch, S.G. and McNamara, J. 1997. Measurement of triglyceride concentration. In: Rifai, N. Warnick, G.R. and Dominiczak, M.H., ed. Handbook of lipoprotein testing. Washington: AACC Press. pp. 115-126.

Daing, M.I., Pathak, A.K., Bhat, M.A. and Zargar, M.A. 2017. Antioxidant and antibacterial potential of condensed tannins containing tree leaves extract. Vet. Pract., 18 (1): 118-121.

Daing, M.I., Pathak, A.K., Bhat, M.A., Sharma, R.K. and Zargar, M.A. 2017. In vitro antioxidant and antibacterial efficacy of condensed tannins containing tree leaves extract of Jammu Province. J. Anim. Res., 7 (1): 165-174.

Doumas, B.T., Arends, R.L. and Pinto, P.C. 1972. Standard methods of clinical chemistry, Academic Press Chicago, Vol. 7: 175-189.

Dube, J. S. 1993. Nutritive value of four species of browse preffered by goats in a redsoil thornveld on Southern Zimbabwe. M. phil. thesis. University of Zimbabwe.

El-Deek, A.A., Asar, M.A., Hamdy, S.M. and Abdalla, A.A. 2009. Utilization of guava by-products in broiler finisher diets. Egypt. Poul. Sci., 29(I): 53-75.

Ewuola, E.O. 2009. Organ traits and histopathology of rabbits fed varied levels of dietary fumonisin B1. J. Anim. Physio. Anim. Nutr., 93: 726-731.

Henry, R.J., Chiamori, N., Golub, O.J. and Berkman, S. 1960. Revised spectrophotometric methods for the determinations of glutamic oxaloacetic transaminase, glutamic pyruvic transaminase and lactic acid dehydrogenase. Am. J. Clin. Pathol., 34: 381-398.
Isaac, O.A., Charles, O.A., Charles, O.N., Omokolade, A.O. and Rotdelmwa, M. 2017. Evaluation of selected agricultural solid wastes on biochemical profile and liver histology of albino rats. Food Feed Res., 44(1): 73-79.

Islam, M.R., Nurealam Siddiqui M., Khatun, A., Siddiky, M.N.A., Rahman, M.Z., Bostami, A.B.M.R. and Selim, A.S.M. 2014. Dietary effect of Mulberry leaf (Morus alba) meal on growth performance and serum cholesterol level of broiler chickens. SAARC J. Agric., 12(2): 79-89.

Jung, Y., Jeon, H.S., Jung, S., Choe, J.H., Lee, J.H., Heo, K.N., Kang, B.S. and Jo, C. 2011. Comparison of quality traits of thigh meat from Korean native chickens and broilers. Korean J. Food Sci. Anim. Res., 31: 684-692.

Kakengi, A.M.V., Kaijage, J.T., Sarwatt, S.V., Mutayoba, S.K., Shem, M.N. and Fujihara, T. 2007. The effect of Moringa olifera leaf meal as a substitute for sunflower seed meal on performance of laying hens in Tanzania. Lives. Res. Rural Develop., 19(8).

Kaneko, J.J. 1997. Clinical Biochemistry of Domestic Animals. Fifth ed., Academic Press, New York, USA, pp. 885-905.

Mahmoud, R.E., Ibrahim, Doaa and Badawi, M.E. 2013. Effect of supplementation of broiler diets with guava leaves and/or olive oil on growth, meat composition, blood metabolites and immune response. Benha Vet. Med. J., 25(2): 23-32.

Makkar, H.P.S. 2000. Quantification of tannins in tree foliage. A laboratory manual for the FAO/IAEA co-ordinated research project on "use of nuclear and related techniques to develop simple tannin assays for predicting and improving the safety and efficiency of feeding ruminants on tanniferous tree foliage". Joint FAO/IAEA working document, IAEA, Viena. Pp 1-26.

Newman, D.J. and Price, C.P. 1999. Renal function and nitrogen metabolites. In Burtis CA and Ashwood ER eds. Tietz Textbook of Clinical Chemistry, $3^{\text {rd }}$ ed. WB Saunders Company, Philadelphia, pp. 1204-1270.

Nworgu, F.C., Alikwe, P.C.N., Egbunike, G.N. and Ohimain, E.I. 2015. Performance and Haematological indices of broiler chickens fed Water Leaf (Talinum triangulare) meal supplement. J. Agric. Ecol. Res. Int., 2(1): 20-20.

Obikaonu, H.O., Okoli, I.C., Opara, M.N., Okoro, V.M.O., Ogbuewu, I.P., Etuk, E.B. and Udedibie, A.B.I. 2012. Haematological and serum biochemical indices of starter broilers fed leaf meal of neem (Azadirachta indica). J. Agric. Tech., 8(1): 71-79.

Pathak, A.K. 2013. Potential of using condensed tannins to control gastrointestinal nematodes and improve small ruminant performance. Int. J. Mol. Vet. Res., 3(8): 36-50.

Pathak, A.K. 2017. Nutritional bases to control gastrointestinal parasites of livestock. J. Dairy Vet. Sci., 4 (2): October, 2017. 
Pathak, A.K., Dutta, N., Banerjee, P.S. and Sharma, K. 2013 a. Effect of tannin extracts from tropical tree leaves on larvae and adult Haemonchus contortus. Indian Vet. J., 90(1): 3234.

Pathak, A.K., Dutta, Narayan, Banerjee, P.S., Sharma, K. and Pattanaik, A.K. 2013b. Efficacy of various condensed tannins extracts from tanniferous tree leaves on egg hatching inhibition of Haemonchus contortus. Vet. Pract., 14(1): 127129.

Pathak, A.K., Dutta, N., Banerjee, P.S., Pattanaik, A.K. and Sharma, K. 2013c. Influence of dietary supplementation of condensed tannins through leaf meal mixture on nutrient intake, utilization and performance of Haemonchus contortus infected sheep. Asian-Aust. J. Anim. Sci., 26(10): 1446-1458.

Pathak, A.K., Dutta, N., Pattanaik, A.K. and Sharma, K. 2016. Influence of condensed tannins supplementation through Ficus infectoria and Psidium guajava leaf meal mixture on nutrient intake and clinical chemistry in lambs. J. Anim. Res., 6(2): $15-25$.

Pathak, A.K., Dutta, N., Pattanaik, A.K., Sharma, K., Banerjee, P.S. and Goswami, T.K. 2017. Effect of condensed tannins supplementation through Ficus infectoria and Psidium guajava leaf meal mixture on erythrocytic antioxidant status, immune response and gastrointestinal nematodes in lambs (Ovis aries). Vet. Arhiv., 87(2): 139-156.

Rahman, Z., Siddique, M.N., Khatun, M.A. and Kamruzzaman, M. 2013. Effect of Guava (Psidium guajava) leaf meal on production performances and antimicrobial sensitivity in commercial broiler. J. Nat. Prod., 6: 177-187.

Roeschlan, P., Bernt, E. and Grnber, W. 1974. Total cholesterol estimation by CHOD-PAP enzymatic method. Clin. Chem., 12: 403.

Shafey, T.M., Almufarij, S.I. and Albatshan, S.I. 2013. Effect of feeding olive leaves on the performance, intestinal and carcass characteristics of broiler chickens. Int. J. Agric. Biol., 15: 585-589.
Simol, C.F., Tuen, A.A., Khan, H.H.A., Chubo, J.K., King, P.J.H. and Ong, K.H. 2012. Performance of chicken broilers fed with diets substituted with mulberry leaf powder. Afri. $J$. Biotechnol., 11(94): 16106-16111.

Singh, S., Pathak, A.K., Khan, Muzaffar and Sharma, R.K. 2016. Effect of tanniferous leaf meal mixture based multi nutrient blocks on nutrient utilization and biochemical profile of Haemonchus contortus infected goats. Indian J. Anim. Res., 50(5): 725-732.

Snedecor, G.W. and Cochran, W.G. 2004. Statistical methods. $8^{\text {th }}$ Edn., East West Press Pvt. Ltd., New Delhi.

Suvarna, K., Layton, C. and Bancroft, J. 2012. Bancroft's Theory and Practice of Histological Techniques. $7^{\text {th }}$ Edn, Churchill Livingstone.

Talpatra, S.K., Ray, S.C. and Sen, K.C. 1940. Estimation of phosphorus, chlorine, calcium, magnesium, sodium and potassium in foodstuffs. Indian J. Vet. Sci. Anim. Husb., 10: 243-258.

Tietz, N. 1976. Fundamentals of clinical chemistry, W.B. Saunders Co. Philadelphia, 1976.

Tietz, N.W. 1986. Text book of clinical chemistry W.B. Saunders Co. Philadelphia, 1351.

Upadhyay, C. 1990. The medicinal properties of neem (Azadirachta indica) tree. In: Animal pharmacology, $2^{\text {nd }}$ Edn, Longman England.

Zargar Mohd. Aqib, Pathak, A.K. and Daing, Mohd. Iqbal 2017. Screening and evaluation of antioxidants and anticoccidial properties of condensed tannins containing tree leaves of Jammu province. Indian J. Anim. Res., 51(6): 1105-1112.

Zargar, Mohd. Aqib, Pathak, A.K., Sharma, R.K. and Daing, Mohd. Iqbal 2016. Antioxidants and Anticoccidial potential of aqueous extract from various tree leaves containing condensed tannins. J. Anim. Res., 6 (4): 563-570. 